\title{
A STUDY TO EVALUATE LIFE SPAN OF CROWNS \& FIXED PARTIAL DENTURES AND VARIOUS REASONS OF THEIR FAILURES
}

\author{
Dr Gursharan Singh ${ }^{1}$, Dr Nishtha Madan ${ }^{2}$ Dr Mandeep Kumar ${ }^{3}$, Dr Cherry Walia ${ }^{4}$, Dr Opinder Pal Singh ${ }^{5}$ \\ ${ }^{1}$ Reader, Department of Prosthodontics, Bhojia Dental College \& Hospital, Distt. Solan, Himachal Pradesh (India) \\ ${ }^{2}$ Reader, Department of Prosthodontics, Bhojia Dental College \& Hospital, Distt. Solan, Himachal Pradesh (India) \\ ${ }^{3}$ Reader, Department of Prosthodontics, Bhojia Dental College \& Hospital, Distt. Solan, Himachal Pradesh (India) \\ ${ }^{4}$ Sr. Lecturer, Department of Oral Medicine, Bhojia Dental College \& Hospital, Distt. Solan, Himachal Pradesh (India) \\ ${ }^{5}$ Post Graduate student, Department of Prosthodontics, Bhojia Dental College \& Hospital, Distt. Solan, Himachal Pradesh (India) \\ Corresponding Author: \\ ${ }^{1}$ Mobile: 919872628508 Email: congurcharan@rediffmail.com
}

\begin{abstract}

Received :
$18^{\text {th }}$ March, 2013
Accepted:
$21^{\text {st }}$ May, 2013
Available online:
$25^{\text {th }}$ August, 2013
\end{abstract}

\section{INTRODUCTION}

Various types of crowns replace all or part of the clinical crowns thereby restoring form function and aesthetics of the damaged teeth. Fixed Dental Prostheses (FDPs) replace one or more missing teeth and are attached definitely to the remaining teeth. The restorative material may be all metal, all porcelain, a metal-ceramic combination, or a metal with processed resin. The aim of all these restorations is to make them as durable as the life of the teeth, but the longevity has always been of great concern for both the patients as well as the clinicians. Analysing the common reasons of failures of FPDs and crowns would help dental surgeons to treat patients with much guarded and predictable prognosis. ${ }^{1}$

Clinical failure may occur during or after an appropriately performed fixed prosthodontic treatment procedure. Failures broadly can be divided into three types i.e. Biologic failure, mechanical failure and aesthetic failure. ${ }^{2}$ A large number of articles present data providing comprehensive comparison of the complications associated with the most commonly used restorations / prostheses.

Studies concerning causes of prosthodontic failures are well highlighted in the dental literature. Article on the subject as published by Schwartz et $\mathrm{al}^{2}$ has provided dental surgeons with information about the most common prosthodontic shortcomings.

A study by Glantz et $\mathrm{al}^{10}$ examined the quality of fixed restorations 5 years after placement and determined that $90 \%$ of crowns and pontics were satisfactory.

The aim of this article is to present data regarding clinically observed complications associated with Crowns and FPDs and highlight various reasons of failures and to compare it with similar studies, as carried out by Walton $\mathrm{JN}$ et al, ${ }^{1}$ Schwartz et al, ${ }^{2}$ regarding length of service and reasons for replacements of fixed dentalprostheses. Lindquist $\mathrm{E}$ and Karlsson $\mathrm{S}$ in their study found failures 
associated with periodontal diseases showing alveolar bone loss, cervical pocket formation and excessive mobility. ${ }^{3}$

\section{MATERIAL AND METHODS}

A survey was carried out in this study to diagnose various cases of failures of crowns and FPDs who reported to this institution for repair or replacement of the same over a period of 18 months. Any fixed dental prosthesis that required repair or replacement were termed as unserviceable. Upon examination the relevant data were collected for various types of the restoration including the reasons of their failures. The aim of the survey was to find out the average life span of the prostheses and the root cause of the failure.

Classification of the failures were based on the reports as published by Walton ${ }^{1}$ et al and Schwartz ${ }^{2}$ et al in order to compare with the earlier researches on the subject. A restoration was termed failure when it needed repair / replacement. Failures due to periodontal diseases exhibited soft tissue diseases, alveolar bone loss, pocket formation, pus discharge and mobility of various degrees.

During the period of 18 months of the survey, a total of 106 patients were assessed. Out of 106 patients, 74 were males and 32 females. Out of 348 number of restoration units examined intra-orally 236 were found to be unserviceable. Satisfactory units which were attached to the failing units were included in the failing unit. Of the multiple reasons of failures seen in the same unit, the main cause of the failure was selected in the survey. The result was analysed based on individual unit even though the same was part of the three unit FPD.

Although a restoration of more than 20 years of survival in the mouth is not considered a failure, the interest shown in this study was to ascertain failure reasons including finding out approximate duration it served successfully inside the mouth.

\section{RESULTS}

Causes of failures as related to the number of failed units, the number requiring replacement and the mean survival time was recorded as shown in Table I. Dental caries was the most common reason of failure (24.2\%) Mean length of the service was found to be 7.5 years. Other reasons of failure after dental caries were defective margins (18.2\%), poor aesthetics $(15.2 \%)$, poor retention $(11.7 \%)$, fractured teeth $(10.6 \%)$, periodontal diseases $(8.8 \%)$, porcelain fracture $(4.2 \%)$, periapical involvement $(5.8 \%)$ and other reasons like wear through occlusal surface, over contoured restoration and fractured amalgam core and poor occlusalplane $(1.3 \%)$.

Reasons for failures were further divided into two groups (Table II). One group represented oral diseases and the other mechanical problems. The oral diseases such as dental caries, periapical lesions, and periodontal diseases accounted for about $38.8 \%$ of the failures. The mechanical problems accounted for $59.9 \%$ failures whereas marginal defects were the main cause of the failure followed by unsatisfactory aesthetics and loss of retention.

Table III represents the relationship between retainer type, reasons for failure and the mean length of service. The metal ceramic crowns had aesthetics as the main cause of failure. Complete coverage / full metal crowns showed caries and defective margin as the common causes of failures. Resin veneered crowns showed perforations as the main reason of failure. Partial veneer crowns showed loss of retention as the cause of failure. Porcelain crowns failed due to fracture/ cracks in the porcelain.

\section{DISCUSSION}

Periodic long term follow up of patients is extremely important for evaluation of success of any prosthesis. If long term success with crowns and FPDs is desired, patients must be periodically recalled to assess not only the restorations but also the supporting tissues. Since the same is not possible for all cases in our environment, evaluation for repair / replacement remains the only method of evaluation for a majority of individuals.

The survey was undertaken to ascertain the causes of failures of crowns and fixed dental prosthesis and to ascertain the average length of service. It was observed that the majority of the restorations were metal ceramic in view of aesthetics, strength and affordability.

Caries accounted for $24.2 \%$ of failures. Causes of failures next to caries were defective margins, aesthetic failure, retention failures, periodontal diseases, fractured tooth, periapical lesions, porcelain 
fracture and others. The mean length of service in consideration of all the foregoing modes was 7.5 years

To allow further comparison Table I contents were rearranged in Table II showing failures due to oral diseases and failures due to mechanical problems. The former included caries, periodontal / periapical diseases and mobility while the latter included defective margins, porcelain failures, uncemented restorations, poor esthetics, won or lost resin veneers, fracture of joint etc.

Since caries proved to be the major reason of failure amongst the various reasons, it becomes necessary to lay emphasis on the relevant factors promoting caries and find measures to rectify the same in order to minimize loss of prostheses. ${ }^{4}$ Oral hygiene practices by the patient and creation of accurately fitting margins of the restoration/ prostheses definitely are going to reduce this failure factor. Caries underneath old fillings must be evaluated / treated in order to prolong the life of the tooth supporting the crown / prosthesis.

The abutment tooth must be evaluated beforehand in order to prevent excess loading thereby leading to mobility and periodontal complications. Any disease process found active in the oral cavity must be treated before initiating restorative therapy. Factors promoting healthy adaptation of the artificial restorations in the mouth such as margins, contours, occlusal surfaces, embrasures, correct pontic design, correct connectors must be taken into consideration to ensure durability of the prostheses. ${ }^{5}$ Tissues supporting the restorations must be maintained in a healthy state to ensure long life of the prostheses. Periodontal disease must be treated before fabrication of the prostheses.

Since mechanical failures account for a large percentage of cases, it is prudent to lay a strong emphasis on the sound principles of FPD fabrication. Tooth preparation must respect the basic essentials like conservation, retention and resistance forms, cervical margin placement etc. A breach in the marginal integrity leads to dental caries which further leads to other complications. Esthetic failures such as colour mismatch, under-contoured or over-contoured surfaces can be rectified in the earlier stages only if due considerations are given to the details of these factors. Porcelain fracture needs adequate precautions at the time of tooth preparation and porcelain build up so that fracture during use can be minimised.

Dental caries has been found to be the single most important reason of failure in various studies. ${ }^{6,7}$ Goodacreet al have also summarised clinical complications in fixed prosthodontics. ${ }^{8}$ Relationship of crown margin placement and gingival inflammation has been shown by Richter WA. ${ }^{9} \mathrm{~A}$ study by Glantz et al examined the quality of fixed dental prostheses 5 years after placement and found $90 \%$ of crowns and pontics were satisfactory. ${ }^{10}$

TABLE I. REASONS FOR REPLACEMENT, BY FREQUENCY

\begin{tabular}{|l|c|c|c|c|}
\hline $\begin{array}{l}\text { Reasons for } \\
\text { replacements }\end{array}$ & $\begin{array}{c}\text { Number of } \\
\text { failed units }\end{array}$ & $\begin{array}{c}\text { Number of units } \\
\text { requiring replacement }\end{array}$ & $\begin{array}{c}\text { Units failed } \\
(\boldsymbol{\%})\end{array}$ & $\begin{array}{c}\text { Mean length of } \\
\text { service in years }\end{array}$ \\
\hline Caries & 57 & 76 & 24.2 & 8.9 \\
\hline Defective margins & 43 & 61 & 18.2 & 7.6 \\
\hline Aesthetics & 36 & 43 & 15.2 & 6.0 \\
\hline Loss of retention & 28 & 34 & 11.7 & 6.9 \\
\hline Tooth fracture & 24 & 33 & 10.6 & 8.6 \\
\hline Periodontal disease & 21 & 31 & 8.8 & 6.9 \\
\hline Periapical involvement & 14 & 30 & 5.8 & 6.8 \\
\hline Porcelain fracture & 10 & 28 & 4.2 & 7.6 \\
\hline Others & 03 & 12 & 1.3 & 8.2 \\
\hline \multicolumn{1}{|c|}{ Total } & $\mathbf{2 3 6}$ & $\mathbf{3 4 8}$ & $\mathbf{1 0 0 \%}$ & $\mathbf{7 . 5 \%}(\mathbf{m e a n})$ \\
\hline
\end{tabular}


TABLE II. REASONS FOR REPLACEMENT: ORAL DISEASES VERSUS MECHANICAL PROBLEMS

\begin{tabular}{|l|c|c|c|}
\hline Cause of failure & Failures & Percentage & Mean service length \\
\hline Oral diseases & & & \\
\hline 1. Caries & 57 & 24.2 & 6.9 \\
\hline 2. Periodontal diseases & 21 & 8.8 & 6.9 \\
\hline 3. Periapical diseases $\quad 14$ & 5.8 & 6.8 \\
\hline$\quad$ Total & $\mathbf{9 2}$ & $\mathbf{3 8 . 8 \%}$ & $\mathbf{7 . 5}$ Years \\
\hline Mechanical problems & & & 7.6 \\
\hline 1. Defective margins & 43 & 18.2 & 6.0 \\
\hline 2. Aesthetics & 36 & 15.2 & 6.9 \\
\hline 3. Loss of retention & 28 & 11.7 & 8.6 \\
\hline 4. Tooth fracture & 24 & 10.6 & 7.6 \\
\hline 5. Porcelain fracture & 10 & 4.2 & $\mathbf{7 . 3 ~ Y e a r s}$ \\
\hline$\quad$ Total & $\mathbf{1 4 1}$ & $\mathbf{5 9 . 9 \%}$ & 8.2 Years \\
\hline$\quad$ Others & 3 & $\mathbf{1 . 3 \%}$ & \\
\hline
\end{tabular}

TABLE III. CROWNS: LENGTH OF SERVICE AND MOST COMMON REASONS OR REPLACEMENT

\begin{tabular}{|l|l|c|}
\hline \multicolumn{1}{|c|}{$\begin{array}{c}\text { Type of restoration } \\
\text { (Crown) }\end{array}$} & \multicolumn{1}{|c|}{ Common cause of failure } & $\begin{array}{c}\text { Mean length of service } \\
\text { in years }\end{array}$ \\
\hline Full veneer metal & Caries, defective margins & $\mathbf{8 . 7}$ \\
\hline Ceramo-metal & $\begin{array}{l}\text { Poor aesthetics, } \\
\text { Porcelain failure }\end{array}$ & $\mathbf{7 . 5}$ \\
\hline Resin veneered metal & Wear, loss of veneer & $\mathbf{6 . 8}$ \\
\hline Porcelain jacket & $\begin{array}{l}\text { Fractured porcelain, } \\
\text { defective margin }\end{array}$ & $\mathbf{6 . 9}$ \\
\hline Partial veneer & Caries, defective margins & $\mathbf{7 . 7}$ \\
\hline & \multicolumn{1}{|c|}{ Mean life in years } & $\mathbf{7 . 5}$ \\
\hline
\end{tabular}

\section{SUMMARY}

In order to ensure true professional service to the patients, understanding various reasons of failures or complications will help in improving prognosis for FPDs service. The results obtained in this study show common trends as compared to similar studies and identify factors that can be used to improve treatment plan for better communication to the patients and ensure optimum success in FPD /restoration service. A positive direct relationship between the life span and the number of units of FDPs was observed.

Failures in FPDs were more due to retainers rather than pontics. Mean length of service of all fixed restoration was found to be 7.5 years. Dental caries was found to be the most common cause of the failure showing approximately 24.2 per cent. It was followed by marginal defect showing 18.2 per cent. Mechanical reasons of failure were 59.9 percent. Partial veneered metal crowns had the longest life span and showed loss of retention as main cause of failure.

\section{REFERENCES}

1. Walton JN, Gardner FM, Agar JR. A survey of crown and fixed partial denture failure: length of service and reasons of replacement. J Prosthet Dent 1986;56:416-21.

2. Schwartz NL, Whitsett LD, Berry TG, Stewart JL. Unserviceable crowns and fixed partial dentures: life span and causes for loss of serviceability. J Am Dent Assoc 1970;81:1395-1401.

3. Lindquist E, Karlsson S. Success rate and failures for fixed partial dentures after 20 years of service: Part I. IntJProsthodont 1998;11:133-8. 
4. Foster LV. The relationship between failures and design in conventional bridgework from general dental practice. J Oral Rehabil 1991;18:491-495.

5 Christensen GJ. Ensuring retention for crowns and fixed prostheses. J Am Dent Assoc 2003;134:993-5.

6. Fayyad MA, al rafee MA. Failure of dental bridges II: Prevalance of failure and its relation to place of construction. J Oral Rehabil 1996;23:438-440.

7. Libby G, Arcuri MR, Lavelle WE. Longevity of fixed partial dentures.J Prosthet Dent 1997;78:127-131.
8. Goodacre CJ, Bernal G, Kitichai R, Kan Joseph YK. Clinical complications in fixed prosthodontics. J Prosthet Dent 2003;90:31-41.

9. Richter WA, Ueno H. Relationship of crown margin placement to gingival inflammation. J Prosthet Dent 1973;30:156-61.

10. Glantz P, Ryge G, Jendresen MD, Nilner K.Quality of extensive fixed prosthodonticsafter five years.J Prosthet Dent 1984;52:475-9.

Source of Support: Nil, Confilict of Interst: None Declared 